International Journal of Instruction

e-ISSN: 1308-1470 • www.e-iji.net
July $2018 \bullet$ Vol.11, No.3

p-ISSN: 1694-609X

pp. 603-616

Received: 06/01/2018

Revision: 28/05/2018

Accepted: $31 / 05 / 2018$

\title{
Herringbone and Tri Focus Steve Snyder Technique: The Techniques for Teaching Reading Comprehension Viewed from Students' Reading Habit
}

\author{
Fathia Rosyida \\ Faculty of Languages and Arts Education, IKIP PGRI Bojonegoro, Indonesia, \\ f.rosyida57@gmail.com
}

\section{Ali Ghufron}

Faculty of Languages and Arts Education, IKIP PGRI Bojonegoro, Indonesia, alghufron.87@gmail.com

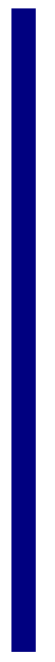

\begin{abstract}
Reading skill plays a pivotal role in the process of acquiring information. An appropriate teaching technique should be implemented in order to improve the students' reading skill. This research aimed at revealing whether or not: (1) Herringbone technique (HT) is more effective than Tri Focus Steve Snyder technique (TFSST) to teach reading comprehension, (2) Students having high reading habit have better reading comprehension than those having low reading habit, and (3) there is an interaction between teaching techniques and students' reading habit in teaching reading comprehension. This research was conducted in one State Junior High School in Indonesia. The research was a quasi-experimental study. The population was 75 students of the ninth-grade. Through cluster random sampling, the samples were chosen. The IX-A class was the experimental group and the IX-B class was the control group. The result of comparing HT and TFSST by using two-way Anova shows that Fobs was 436.6268 while the $\mathrm{F} \alpha$ with the significant level of 0.05 was 4.0471 . Therefore, it implies that HT is more effective than TFSST in teaching reading comprehension. The result of comparing high and low reading habit by using two-way Anova shows that Fobs was 43.3862 while the $\mathrm{F} \alpha$ with the significant level of 0.05 was 4.0471 .
\end{abstract}

Keywords: herringbone technique, reading comprehension, reading habit, Tri Focus Steve Snyder technique, theaching

\section{INTRODUCTION}

Many experts who conducted studies over the last three decades have changed our view of reading as a mere form of decoding process (Alyousef, 2006). The studies revealed that reading is not only a decoding process but also a process that involves both mental and physical activities, such as guessing meaning from context, defining expectations, making inferences, etc. In reading, people will try to find the meaning of what they read

Citation: Rosyida, F., \& Ghufron, M. A. (2018). Herringbone and Tri Focus Steve Snyder Technique: The Techniques for Teaching Reading Comprehension Viewed from Students' Reading Habit. International Journal of Instruction, 11(3), 603-616. https://doi.org/10.12973/iji.2018.11341a 
(Grasser, Singer, \& Trabasso, 1994), and meaning is built through readers' active cognitive interaction with the text (Nuttall, 2005). This active involvement of readers in the construction of meaning is reflected in their use of not only linguistic knowledge, but also background knowledge, world knowledge, personal experiences, and inferences during reading (Grabe \& Stoler, 2002). Grabe (1991) describes reading as an

active process of comprehending [where] students need to be taught strategies to read more efficiently (e. g., guess from context, define expectations, make inferences about the text, skim ahead to fill in the context, etc.

Moreover, research and practice in TESOL was greatly influenced by Krashen's hypotheses on language acquisition, and particularly the effect of "the Schema Theory" on studies dealing with reading comprehension. Today, a growing body of empirical research attests to the role of schemata in EFL (English as a Foreign Language)/ESL (Englih as a Second Language) reading comprehension. Most of the research was made on reading comprehension of the first language. However, insights were adapted to suit SL reading comprehension studies. Most important of all, specific attention is given to interactive approaches to reading, which argue that reading comprehension is a combination of identification and interpretation skills. Grabe (1991) lists the five most important areas of current research which are still prominent: "schema theory, language skills and automaticity, vocabulary development, comprehension strategy training, and reading-writing relations". Automaticity may be defined as "occurring when the reader is unaware of the process, not consciously controlling the process, and using little processing capacity.

In Indonesia, the students in junior high schools are expected to be able to master short functional texts and essays such as descriptive, recount, narrative, and report essay. Further, they are also expected to know the aspects of grammatical features and generic structures of certain genres. Besides, the students are also urged to explore their thinking and identify what the author means through reading passages. However, Indonesian English teachers still find their students face difficulties in EFL reading comprehension even though they have implemented various teaching techniques to help their students to improve their reading skills (Gani, Yusuf, \& Susiani, 2016; Harida, 2014; Mudra, 2016; Satriyani, Moerdibjon, \& Prayogo, 2016; Yusuf, Fajrina, \& Sari, 2016). As stated in the National Education Standards Board of Indonesia (Badan Standar Nasional Pendidikan Indonesia or BSNP) (2007), the goal of teaching English at Junior High Schools is to support the student in achieving their competencies to: (1) increase their communicative competencies, oral or written, to achieve functional literacy level: (2) have awareness about the importance of English to increase the Indonesian capability in competing with other nation in the world; and (3) increase students' understanding of language and culture.

Reading is a receptive skill. It plays a pivotal role in the process of acquiring information. According to Nunan (2003), reading is a fluent process of readers combining information from a text and their background knowledge to build meaning. Moreover, he explains reading as a meaningful interpretation of printed or written symbols. Thus, the reader should be able to acquire ideas from the written text to 
construct text meaning. Reading is the instantaneous association of these symbols with existing knowledge and comprehension of the information or ideas communicated.

In reading, readers must comprehend the meaning of the printed material. Balajthy \& Lipa-Wade (2003) explain that comprehension involves assembling the meanings of individual symbol and words, and integrating and interpreting several meanings in order to obtain the whole meaning. Comprehension requires students to bring something, they should take more from the symbol and word that they brought to it. What the students bring to the symbol is knowledge of words meanings of concept.

In this present research, the researchers who conducted the teaching internship in one Junior High School in Bojonegoro, East Java Indonesia found that the ninth-grade students have problems related to their reading comprehension. Those problems were mainly in finding the main idea in a paragraph. In reading comprehension, the reader must understand text structure; that is, how the main ideas and supporting details of the text are organized (Amer, 1992). The supporting details are more specific sentences that help clarify, prove or suggest the topic sentence by providing reasons, examples, studies, definitions, and many others (Flemming, 2011). While for the other three aspects of reading comprehension, which are reference, inference, and vocabulary, the students are not really confused.

To overcome those problems, the researchers tried to use Herringbone technique (hereafter, HT) because this technique can help students find out the main idea of the text. The herringbone is a technique that used to find the main idea and important information (explicit and implicit) in the text by asking six comprehension question; Who?, What?, When?, Where?, Why? and How? questions in visual diagram of a fish skeleton (Deegan, 2006; McKnight, 2010). Using the answer to the WH questions, the students write the main idea across the backbone fish diagram. McKnight (2010) defines HT as a graphic organizer that is used for establishing supporting details for a main idea. It is a tool to help students recognize the important relationships in the material of reading texts. This is done by answering the 'who, what, when, where, why, and how' questions of a text (Balajthy \& Lipa-Wade, 2003) on a visual diagram of fish skeleton (Thaler, 2008). It facilities the student with an interesting pattern, such as shown in Figure 1:

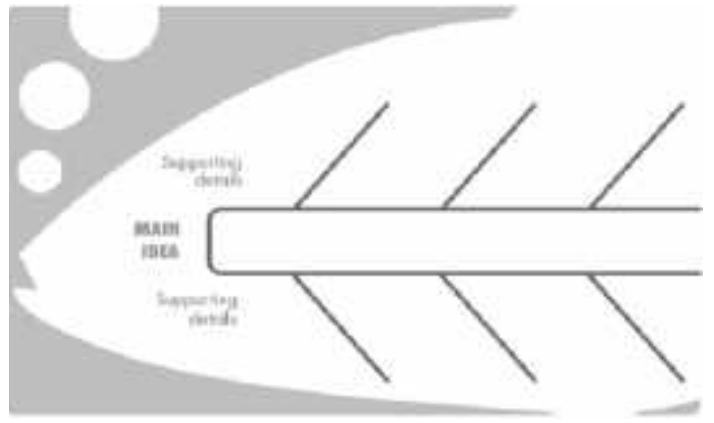

Figure 1

Herringbone Diagram (Source: McKnight, 2010, p. 51) 
In this research, the researcher also used Tri-Focus Steve Snyder Technique (hereafter, TFSST) to be compared with HT. Tri-Focus Steve Snyder Technique is a technique that prioritizes reading peripherals. It stresses fun reading activities. There is no direct correction for mistakes, since the main aim is building students' interest and motivation. This technique can be taught to children to be able to develop their peripheral vision with tri focus training (De Porter, 2008).

The other thing that can affect the students' reading comprehension is student's background knowledge. The students' background knowledge can be extended through reading habit. According to Palani (2012), reading habit is an essential and important aspect of creating a comprehension. Ogbodo (2010) explains that reading habit refers to the behaviour which expresses the fondness of reading of individual. Similarly, Sing (2011) states that reading habits throughout the text are how often, how much, and what students read. Then, some researchers conclude that reading habit is relative to students' gender, age, educational background, academic performance and professional growth.

Gallo (2007) mentions the indicators of reading habits are: (1) Attitude toward reading: the reason that a reader reports on the attitude and behavioural cognitive-affective attitude towards reading; (2) Reading frequency: the frequency at which a reader reports to read books in his unoccupied time; (3) The number of books that reader reports having read in the last three months; (4) Time spent on academic reading: the time that a reader reports to devote to reading books on his study subjects; (5) Motivation in the family environment: often reported by a reader on the purchase of books, recommending books and reading interest in the family; and (6) Motivation in the academic environment: the frequency a reader reports on the teacher using activities to promote contact with psychology literature.

In this research, the researcher were interested in conducting an experimental research with by implementing HT and TFSST in teaching reading comprehension viewed from students' reading habit. Through this study, the researchers wanted to confirm the effectiveness of HT compared to TFSST in teaching reading comprehension. Not only that, the researchers also wanted to confirm whether or not reading habit affects students' reading comprehension, and whether there is an interaction effects between teaching techniques and reading habit.

\section{Research Questions}

From the background of the research above, the researcher formulates the statement of problems as follows.

1. To what extent is HT more effective than TFSST to teach reading comprehension?

2. How is the students' reading comprehension of those having high reading habit compared to those having low reading habit?

3. Is there any interaction between teaching technique and students' reading habit in teaching reading comprehension? 


\section{Research Objectives}

Based on the formulated research questions above, the objectives of the study are:

1. To measure and analyse the extent to which HT is more effective than TFSST to teach reading comprehension.

2. To measure and analysed the students' reading comprehension of those having high reading habit compare to those having low reading habit.

3. To know whether or not there is an interaction between teaching technique and students' reading habit in teaching reading.

\section{LITERATURE REVIEW}

There are various previous studies which used the HT to develop the EFL students' reading comprehension in Indonesian context. Among them are those conducted by Margaretta, Ihksanudin, \& Husin (2015;) Sholichah, (2015); Ningrum \& Widyawati, (2015); and Firda, Rasyidah, \& Kasyulita, (2016) to test various types of English texts on their students by using this technique. Margaretta, Ihksanudin, \& Husin (2015) employed the Herringbone technique to improve reading comprehension on descriptive texts for second grade students of a junior high school. Solichah (2015) implemented HT to the first-grade students of a junior high school to comprehend narrative texts. Moreover, Firda, Rasyidah and Kasyulita (2016) studied the effect of HT towards reading comprehension in recount texts for second grade junior high school students. These experimental studies revealed that the students' reading scores in their post-tests significantly increased after the implementation of HT compared to their pre-tests before the technique was given as treatments. Thus, their research findings basically conclude that HT gave positive effect toward students reading comprehension. HT was also successful in developing their comprehension by increasing attention on detail information. This is because the interesting patterns of graphic diagram help students to organize and classify information on the assigned reading text (McKnight, 2010).

Besides, there are also some studies on the implementation of TFSST in teaching reading. Rahayu (2017) investigated the implementation of TFSST and intensive reading technique to teach reading comprehension in Vocational High School. The results revealed that TFSST is significantly differ from intensive reading technique to improve students' reading comprehension. In this case, TFSST yielded better reading comprehension. Artawati, Kristiantari, and Suara (2014) implemented TFSST to improve reading speed. The results revealed that TFSST is effective to teach reading speed. However, this study was in the context of primary school students. Further, Waryani (2016) also conducted a study on the use of TFSST to improve reading speed for Junior High School students. In her action research, after implementing TFSST for 2 cycles, it was revealed that TFSST is effective in improving students' reading speed. Sari (2010) conducted a research on the influence of TFSST towards the improvement of effective reading. Her study reported that there is significant influence of the implementation of TFSST towards effective reading skill. However, this present study was focused on comparing the HT and TFSST in teaching reading comprehension in Junior High School context. The comparison between these two techniques was based 
on the consideration that in this case, the researchers implemented these techniques in Junior High School (JHS) context. In JHS, reading comprehension and reading speed is urgently needed especially when the students face the National Examination. In the National Examination, the students are not only urged to have good reading comprehension, but also reading speed since the time allotment is limited. Reading comprehension and reading speed are interrelated. Snyder (2011), the founder of TFSST, emphasizes that one of the characteristics of TFSST is that it is aimed at building students' reading speed and reading comprehension. Further, he elaborates that because TFSST changes the reading ability (from one word at a time) become reading in a "new way" (more than one word at a time), it can improve both reading comprehension and vocabulary building. Besides, this study also used the third variable (moderator variable), it is reading habit. Since this study also used reading habit as the moderator variable, therefore, it is suitable if the researchers implemented HT and TFSST. Both of HT and TFSST are suitable to teach reading comprehension.

\section{METHOD}

In this study, the researcher used quasi-experimental design. Quasi-experimental design is sometimes called natural experiments because membership in the treatment level is determined by conditions beyond the control of the experiment. An experiment may seem to be a true experiment, but if the subjects have not been randomly assigned to the treatment condition, the experiment is quasi-experiment (Creswell, 2009).

This experimental study involves three kinds of variables. They are the independent variable, dependent variable, and moderator variable. The independent variable in this research is the teaching technique. They are HT and TFSST. The second variable is the dependent variable. It is the factor which is observed and measured to determine the effect of the independent variable. The dependent variable in this research is reading comprehension of the ninth grade students. The third variable in this research is students' reading habit. It is categorized into two different levels, the high and the low reading habit.

\section{The Population and Sample}

In this research, the researcher took the ninth-grade students of Junior High School 2 of Kedungadem, Bojonegoro, Indonesia, in the academic year 2016/2017 as a population. The total student was 75. The sample of this research was class IX-A and IX-B. The IXA was the experimental class, with the total number of the students was 26 students. And the IX-B was the control class with the total number of 25 students. In determining the 2 classes, the researcher used cluster random sampling. The first class he randomly took was the experimental class and the second was the control class.

\section{Research Instruments}

\section{Questionnaire}

The questionnaire here was to collect data of students' reading habit. The researcher administered a reading habit questionnaire to know how often, how many and what students read. The form consist of 34 question, the items are in objectives form (multiple 
choice). It is used to make students easier to answer. This questionnaire was firstly tested its internal consistency, content validity and reliability before it was distributed to the students.

\section{Documentation}

The researcher used documentation for balancing test instead of pre-test. The data from the first-semester test was analysed to know whether or not the two classes have the same starting point or in balance condition. Balancing test, in an experimental research, is a must since it is important to do before a conclusion is drawn. Therefore, the difference of the two groups at the end of research can be inferrred that it is because of the different treatment given, not because of an unbalanced-condition.

Post-test

Post-test is to collect the data after treatment. The post-test is very important because from the test the researcher can get the data and know the effectiveness of the technique. The researcher used multiple choices to get the result. The test instrument was firstly tested its validity and reliability before it was tested to the students.

\section{Validity and Reliability}

The validity and reliability are pivotal to determine the appropriateness and usefulness of an instrument. In this study, the readability of the reading text was tested first by using Flesch Kincaid formula. It was to find out whether or not the reading text was appropriate to the level of reading comprehension of the sample. Flesch Kincaid readability tests are designed to indicate comprehension difficulty when reading a passage of contemporary academic English. There are two tests, the Flesch Reading Ease and the Flesch Kincaid Grade Level. Although they use the same core measures (word length and sentence length), they have different weighting factors, so the results of the two tests correlate approximately inversely; a text with comparatively high score on the Reading Ease test should have a lower score on the Grade Level Test.

\section{Validity}

After the instrument was measured by using Flesch Kincaid formula, the items of the test were validated which was known as content validity. It helps to determine how well test score represent certain learning objectives as Downie \& Heath (1974) said that as a result of the item analysis of content validity, the kinds of information can be obtained concerning with the items: (1) the difficulty of the item, (2) the appropriateness of the item, and (3) the discrimination index of the item. The content validity depends on a careful analysis of the language being tested and of the particular course objectives.

The items of the test were tried out to the same characteristic of pupils like the sample which was IX-C class of Junior High School 2 of Kedungadem, Bojonegoro, Indonesia. The result, then, was validated and tested its level of difficulty. The level of difficulty categorizes the items into three, i.e. difficult, medium, and easy. If $p$ (the difficulty index) is $0.00-0.30$, the item has high difficulty level; if $p$ (the difficulty index) is 0.31 -0.70 , the item has medium difficulty level; and if $p$ (the difficulty index) is $0.71-$ 
1.00 , the item has low difficulty level (easy). The results showed that from the 50 items desirable, 22 items have medium difficulty level, 10 items have high difficulty level, and 18 items have low difficulty level. Then, the researchers decided to take only 30 items; 20 medium items, 5 easy items and 5 difficult items. Therefore, the test of reading comprehension for the post-test consists of 30 questions of the multiple choice test.

\section{Reliability}

After the validity of the test was found, the test was continued to be tested to find out the reliability of the test. The data which are reliable could be assumed as valid but not all of the data which are valid could be assumed as reliable. Therefore, the data which were not valid has not been used and the remains were measured to find out the reliability. The results of the data from the try out then were analysed their reliability by using Alpha Cronbach; it is a coefficient of reliability. It is commonly used as a measure of the internal consistency or reliability of a psychometric test score for a sample of examinees. As the result, the Cronbach's Alpha was 0.639. If the result $>0.70$, it means that the data is reliable. Therefore, it could be assumed that the data was reliable.

\section{Reseach Procedures}

Firstly, the researcher used the documentation of the results of the previous semester test to know the students' initial condition. In an experimental study, the samples that will be compared and treated by using different treatment must be in balance condition (have the same starting point). They must have the same starting point. Besides, the teacher also gave the students a reading habit questionnaire. After the questionnaire was fulfilled by the students, it is, then, analysed to know the students' level of reading habit (whether they have a high reading habit or low reading habit). After that, the researcher treated the two classes by using different treatment. The experimental class was treated by using Herringbone technique to teach reading comprehension. The control class was treated by using Tri Focus Steve Snyder technique in teaching reading comprehension. After six meetings, the students from the two classes were tested their reading comprehension by using multiple choice test. The results of the post-test was firstly analysed their normality and homogeneity. Then, the data was tested by using 2-way Anova to answer the hypothesis.

\section{FINDINGS AND DISCUSSION}

\section{The Results of Previous Semester Test (Documentation)}

In this study, the initial data was taken from students' reading test in the first semester. It is used to know initial condition between experimental class and control class. Based on the data taken from school, the data is presented in table 1 below:

Table 1

The Summary of Initial Data

\begin{tabular}{lcccccc}
\hline Class & $\mathrm{N}$ & $\sum \mathrm{X}$ & Mean & $\mathrm{s}$ & $\mathrm{X}_{\max }$ & $\mathrm{X}_{\min }$ \\
\hline Experimental & 26 & 2115.6 & 67.49 & 4.9757 & 80.3 & 52 \\
Control & 25 & 1999 & 67.23 & 3.574 & 80.6 & 51 \\
\hline
\end{tabular}




\section{The Results of Reading Habit Questionnaire}

The data of students' reading habit was taken from the questionnaire. The students' reading habit was classified into two categories, i.e. high and low reading habit. The students will be categorized to have the high if their score is higher or equal to median (Score $\geq \mathrm{Me}$ ), and they will be categorized to have low reading habit if their score is lower than median (Score $<\mathrm{Me}$ ). The data of students' reading habit is presented in table 2 below:

Table 2

The Summary of Students' Reading Habit

\begin{tabular}{lllll}
\hline & High Reading & Low Reading & Total & Mean \\
& Habit & Habit & Students & \\
\hline Experimental & 68.4 & 60.27 & 26 & 64.96154 \\
Control & 66.67 & 57.77 & 25 & 62.04 \\
Total Students & 27 & 24 & & \\
Mean & 74.63 & 71.46 & & \\
\hline
\end{tabular}

\section{The Results of Post-test of Reading Comprehension}

After the two groups were treated by using different treatment for 6 meetings, the two groups, then, were tested their reading comprehension. The results of the post-test is presented in table 3 below:

Table 3

The Results of Post-test

\begin{tabular}{lllllll}
\hline Class & $\mathrm{N}$ & $\sum \mathrm{X}$ & Mean & $\mathrm{s}$ & $\mathrm{X}_{\max }$ & $\mathrm{X}_{\min }$ \\
\hline Experimental & 26 & 2015 & 77.50 & 7.7782 & 90 & 60 \\
Control & 25 & 1700 & 68 & 10.2062 & 85 & 50 \\
\hline
\end{tabular}

The Results of Hypothesis Testing

To verify the hypotheses, the data was tested by using two-way Anova. However before the data ws analysed by using two-way Anova, it was firstly tested its normality and homogeneity as prerequisite testing. The summary of two-way Anova is presented in table 4 below:

Table 4

The Summary of Two-way Anova

\begin{tabular}{lllllll}
\hline \multicolumn{1}{c}{ Source of variance } & $\mathrm{SS}$ & $\mathrm{df}$ & $\mathrm{MS}$ & $\mathrm{F}_{\mathrm{obs}}$ & $\mathrm{F}_{\alpha(.05)}$ & Conclusion \\
\hline $\begin{array}{l}\text { Between columns } \\
\text { (teaching techniques) }\end{array}$ & 5080,1666 & 1 & 5080,167 & 436,6268 & 4,0471 & $\begin{array}{l}\mathrm{H}_{\mathrm{o}} \text { is } \\
\text { rejected }\end{array}$ \\
$\begin{array}{l}\text { Between rows (level } \\
\text { of reading habit) }\end{array}$ & 504,7998 & 1 & 504,7998 & 43,3862 & 4,0471 & $\begin{array}{l}\mathrm{H}_{\mathrm{o}} \text { is } \\
\text { rejected }\end{array}$ \\
$\begin{array}{l}\text { Columns by rows } \\
\text { (interaction) }\end{array}$ & 25,5292 & 1 & 25,5292 & 2,1942 & 4,0471 & $\begin{array}{l}\mathrm{H}_{\mathrm{o}} \text { is } \\
\text { accepted }\end{array}$ \\
$\begin{array}{l}\text { Within groups } \\
\text { Total }\end{array}$ & 546,8465 & 47 & 11,6350 & - & - & - \\
\hline
\end{tabular}




\section{HT Compared to TFSST in Teaching Reading Comprehension}

Based on the analysis of two-way Anova, it was obtained that $F_{\text {obs }}=436.6268$ is higher than $\mathrm{F}_{\alpha}=4.4071$. Therefore, it is implied that the students taught by using HT have significant difference in reading comprehension between those taught by using TFSST. Based on the mean score, students who were taught by using HT obtained 77.5; whereas the students who were taught by using TFSST obtained 68 , so it can concluded that students who were taught by using HT is better than the students who were taught by using TFSST.

HT is more effective because it has some advantages in making the students easier to get detail information. Edwards (2004) states that HT involves reading, note taking and comprehension of the main idea and supporting details. This is also in line with Yusuf, Fajrina, \& Sari (2016), who state that the implementation of HT have developed the students' reading comprehension in an EFL classroom, specifically in finding the main idea and the supporting details. However, the researchers also found the disadvantages of this technique while it was implemented in the reading class. That is, when students learn the reading text through graphic representations, their efforts in note-taking were decreased. It is renowned that taking notes while reading is among the support strategy in meta-cognitive awareness of reading strategies that a reader can employ to better understand a text (Fitrisia, Tan, \& Yusuf, 2015). It may not be the most efficient strategy since there are many others and they differ from one individual to another, but note-taking does assist readers in concentrating on the information they read and staying focus on the points relevant to the purpose of reading. It is a strategy that is applicable in managing information (Lo, 2013). Even though this slight drawback did not inhibited the students in improving their reading scores after the treatments, thus the researchers suggest that perhaps, in the future, teachers can apply the HT with note-taking alongside each other in the classroom practice for a more heightened development in reading comprehension.

The Students' Reading Comprehension between Those Having High and Low Reading Habit

From the two-way Anova test, the researchers found the significant difference between the students who have high reading habit and those who have low reading habit. The significant difference can be seen from $F_{o b s}=43.3862$ which was higher than $F_{\alpha}=4.0471$. It means that the students having high reading habit have better reading comprehension than those having low reading habit.

The students who have high reading habit tend to easiky understand EFL passages because they like reading and have a high motivation to always read. Ogbodo (2010, p. 9) state that reading habit refers to the behaviour which expresses the fondness of reading. Whereas, the students who have low reading habit do not interest to always read. They have less motivation to get new information and open new ideas. 
The Interaction between Teaching Techniques and Students' Reading Habit in Teaching Reading Comprehension

Based on the analysis of two-way Anova, it was obtained that $\mathrm{F}_{\mathrm{obs}}=2.1942$ is lower than $\mathrm{F}_{\alpha}=4.4071$. It means that there is no interaction between teaching technique and students reading habit. The factor that cause there is no interaction between teaching techniques and reading habit to teach reading comprehension was HT always results better reading comprehension than TFSST in every group (for both of the students having high and low reading habit) since HT is easier done than TFSST. As Arriyani \& Aryanti (2014) state that the students in the class were active during the implementtaion of HT. They could fill the Herringbone diagram easily. HT also gives the students an opportunity to identify the main idea and the related supporting ideas of a lesson, text or concept since HT is designed to help students organize important information in a text chapter. The students were actively instructed that they would be seeking the answers to the questions and would be recording their answers on the Herringbone diagram as they read the material. Besides, it was also found that their motivation to learn English especially in reading increased significantly.

On the contrary, in control class (in which TFSST was imlemented), there is no significant difference of reading comprehension between the students who have high reading habit and the students who have low reading habit. Even the students having high reading habit who are taught by using TFSST have lower mean score than those having low reading habit who are taught by using HT. This seems to happen because TFSST is difficult to be interpretd by the students. therfore, teachers must explain this technique as clear as possible to the students before teaching and learning process. This, of course, needs more time allotment.

\section{CONCLUSION}

In light of the research findings and discussion, it can be concluded that: (1) HT is more effective than TFSST to teach reading comprehension; (2) The students having high reading habit have better reading comprehension than students having low reading habit; and (3) There is no interaction effect between teaching technique and students' reading habit in teaching reading comprehension.

The implementation of HT to overcome the students' problem in reading comprehension is successful. The students get benefit from modelling the use of this graphic organizer on a chart paper. In implementing the Herringbone technique, students are encouraged to organize and classify the information while they are reading. Herringbone Technique as one of graphic organizer used for establishing supporting details for a main idea is an effective tool to improve the students' comprehension.

This study leads to some implications especially for the teacher training program and school management in Indonesia dealing with the teaching and learning process of EFL reading skill. They should pay more attention to reading skill, especially for the ninthgraders, by driving the EFL pre-service teacher and in-service teacher to implement, or even create teaching technique which could cope not only the core materials but also the techniques that can improve students' reading habit. Reading habit plays a pivotal role 
in this case. Whatever the teaching technique used, the students who have high reading habit will tend to have good reading comprehension. Therefore, for the students, it is urgently needed to have high self-awareness in reading habit.

The researchers found a number of limitations in this study. Therefore, for future studies, the researchers suggest that the control group can be put into operation in the experiment so that a clearer comparison of those students treated with and without HT is more well-defined. Larger samples, different level of students, and different institutions are also recommended. It is also proposed that researchers also deepen their study by collecting students' responses on the use of HT in teaching reading in order to foster teachers in formulating better lesson plans in using this technique.

\section{REFERENCES}

Alyousef, H. S. (2006). Teaching reading comprehension to EFL/ESL learners. Journal of Language and Learning , 5 (1), 63-73.

Amer, A. (1992). The effect of story grammar instruction on ESL students' comprehension of narrative, Reading in a Foreign Language, 8(2), 711-720.

Arriyani, N., \& Aryanti, N. (2014). Improving reading comprehension achievement by using folktales through Herringbone technique. SULE-IC (p. 129-139). Palembang: Faculty of Teacher Training and Education, Sriwijaya University.

Artawati, N. K., Kristiantari, M. G. R., \& Suara, I. M. (2014). Penerapan teknik Tri Focus Steve Snyder pada peningkatan kecepatan efektif membaca (KEM) mata pelajaran bahasa indonesia siswa kelas 4 SD Negeri 2 Rendang tahun pelajaran 2012/2013. e-Journal Mimbar PGSD Universitas Pendidikan Ganesha Jurusan PGSD, 2 (1). Retrieved from: https://ejournal.undiksha.ac.id/index.php/JJPGSD/article/view/4124

Balajthy, E., \& Lipa-Wade, S. (2003). Struggling readers: Assessment and instruction in grade $K-6$. Guilford Press.

Badan Standar Nasional Pendidikan. (2007). Permendiknas RI Nomor 41 Tahun 2007. Jakarta: BSNP.

Creswell, J. W. (2009). Research design: qualitative, quantitative, and mixed methods approaches (third edition). Newbury Park: Sage Publications.

De Porter, B. (2008). Quantum learning: Membiasakan belajar nyaman dan menyenangkan. Bandung: Kaifa.

Deegan, J. (2006). Herringbone Technique. Accessed on August 12, 2017, from http://www.teacherweb.com/PA/NazarethAreaMiddleSchool/TheSpecialist

Team/HerringboneTechnique.doc

Downie, F., \& Heath, S. (1974). Research in education. Englewood Cliffs, NJ: PrenticeHall International, Inc. 
Edwards, P. (2004). Literacy techniques for teachers and parents (3rd edition). Bloomington: Trafford Publishing.

Firda, N., Rasyidah, U., \& Kasyulita, E. (2016). The effect of Herringbone technique toward student reading comprehension of Recount text at the grade VIII students of SMPN 4 Rambah Hilir. Riau: University of Pasir Pengairan.

Fitrisia, D., Tan, K. E., \& Yusuf, Y. Q. (2015). Investigating metacognitive awareness of reading strategies to strengthen students' performance in reading comprehension. Asia Pacific Journal of Educators and Education, 30, 15-30.

Flemming, L. E. (2011). Reading for thinking. Cengage Learning.

Gallo, D. (2007). Reading interest and habits of Connecticut students at grades four through twelve. The Reading matrix , 2 (3), 1-20.

Gani, S. A., Yusuf, Y. Q., \& Susiani, R. (2016). Progressive outcomes oc collaborative strategic reading to EFL learners . Kasetsart Journal of Social Sciences , 37 (3), 144149 .

Grabe, W. (1991). Current Development in Second Langauge Learning Research. TESOL Quarterly , 25 (3), 374-406.

Grabe, W. \& F. L. Stoller. (2002). Teaching and researching reading. Essex, UK: Longman.

Graesser, A. C., M. Singer \& T. Trabasso. (1994). Constructing inferences during narrative text comprehension. Psychological Review, 101(3), 371-395.

Harida, E. S. (2014). Students' ability and difficulties in understanding English text (A study at English Program IAIN Padangsidimpuan). Al-Ta'lim Journal , 3, 183-188.

Lo, C. L. (2013). The impact of note-taking in counselling. Accessed on September 21, 2017, from http://ir.uiowa.edu/etd/2569/

Margaretta, Ihksanudin, \& Husin, S. (2015). Teaching reading descriptive text using Herringbone technique: A pre-experimental research at SMP Negeri 8 Pontianak in academic year 2013/2014. Jurnal Pendidikan dan Pembelajaran UNTAN. Retrieved from: https://media.neliti.com/media/publications/211900-none.pdf

McKnight, K. S. (2010). The teacher's big book of graphic organizers: 100 reproducible organizers that help kids with reading, writing, and the content areas. John Wiley \& Sons.

Mudra, H. (2016). Enhancing students' speaking skill through task-based language teaching (TBLT) at English tadris department of STAIN Kerinci. Al-Ta'lim Journal , 23 (1), 78-87.

Ningrum, A. S., \& Widyawati, I. (2015). Improving students' reading comprehension skill using Herringbone technique at MTs Al-Fatah Badas. Permalink , 9 (2), 397-416. 
Nunan, D. (2003). Practical English language teaching. New York: Mc Graw Hill Companies Inc.

Nuttall, C. (2005). Teaching reading skills in a foreign language (3rd edn.). Oxford: MacMillan.

Ogbodo, R. O. (2010). Effective study habits in educational sector: Counselling implication. Edu Journal of Counselling , 3 (2), 1-11.

Palani, K. K. (2012). Promoting reading habits and creating literate social. International Reference Research Journal , 27 (3), 1-12.

Rahayu, E. S. (2017). The use of Tri-focus Steve Snyder and Intensive Reading techniques to teach reading comprehension (Experimental research of the first grade students of SMK Muhammadiyah 7 Wonosegoro in the academic year of 2016/2017). Salatiga: IAIN Salatiga. Retrieved from: http:/lerepository.perpus.iaiansalatiga.ac.id/2166/

Sari, R. M. (2010). Pengaruh penerapan teknik pembelajaran Tri Focus Steve Snyder terhadap peningkatan kemampuan membaca efektif. Retreived from: http://jurnal.unimed.ac.id/2012/index.php/kultura/article/viewFile/1791/1442

Satriyani, L., Moerdibjon, A. W., \& Prayogo, J. A. (2016). Employing graphic organizers through team-pair-solo strategy to improve reading comprehension of eighth graders at SMPN 9 Kubung. Al-Ta'lim Journal , 23 (1), 37-51.

Sholichah, M. A. (2015). Improving the students' reading comprehension by using Herringbone technique at the seventh grade of class-B of SMPN 2 Deket. Jurnal FKIP Unisla , 1 (1), 42-46.

Sing, Y. G. (2011). Academic achievement and study habits of higher secondary students. International Refereed Journal , 27 (3), 1-12.

Snyder, S. (2011). Steve Snyder Seminar. Journal of Mind Matters Part 2. Retrieved from: http://www.stevensnyderseminars.comPDFsMindMattersPart2.pdf

Thaler, E. (2008). Teaching English Literature. Paderborn: Schoningh, UTB.

Waryani, D. N. (2016). The use of Tri Focus Steve Snyder technique to improve the students on reading speed skills for the second grade students of MTs Negeri Cepogo Boyolali in the academic year 2015/2016. IAIN Salatiga. Retrieved from: http://erepository.perpus.iainsalatiga.ac.id/735/1/DEWI\%20NUR\%20WARYANI.pdf

Yusuf, Y. Q., Fajrina, D., \& Sari, I. (2016). Developing the EFL reading comprehension by employing herringbone technique. Al-Ta'lim Journal , 23 (3), 183-190. 